\title{
FURTHER RECORDS AND DESCRIPTIONS OF FLEAS FROM ECUADOR.
}

\author{
BY DR. KARL JORDAN. \\ (With 12 text-figures.)
}

\begin{abstract}
$\mathrm{W}^{\mathrm{B}}$ E are very much indebted to Dr. F. Spillmann for a further consignment of Siphonaptera, collected by him in the highlands of Ecuador during April 1931. The collection extends our knowledge of the range of several genera and renders it also possible to clear up some points in taxonomy which had to be left in abeyance for lack of adequate material. It is especially worthy of note that the collection contains no less than 5 species of Helmed Fleas, allied to the Australian genus Stephanocircus Skuse 1893.
\end{abstract}

\section{Pulex irritans L. 1758.}

Iliniza, off Coenolestes spec., 1 os ; an accidental occurrence, the flea probably having been derived from the native who handled the mammal.

\section{Tetrapsyllus gen. nov.}

Parapsyllus sect. E., Jord. \& Roths., Eetoparasites 1, p. 365 (1923).

ऽ우. The receipt of a further species convinces me that section $\mathrm{E}$ of our Revision, l.c., should be regarded as constituting a genus separate from Parapsyllus Enderl. 1903. Labial palpus with four instead of five segments. Gena with a ventral marginal row of bristles from below the eye to the posterior angle. Hindcoxa only about one-fifth longer than broad, being broader than in Parapsyllus. Abdominal sternite VI (not VII) of $q$ with a small lateral sinus ; spermatheca with the orifice on a more or less prominent cone.-Genotype: Parapsyllus cocyti Roths. 1904.

2. Tetrapsyllus comis spec. nov. (text-fig. 1).

․ Near to T. tantillus J. \& R., l.c., p. 367 no. 16 text-fig. 382 (1923) (Argentina) ; distinguished by the much shorter bristles of the antennal segment II, the shorter and stouter bristles of the legs, the smaller sinus of sternite VI, etc.

Genal margin with a row of about 9 bristles ; 3 large eye-bristles, with small hairs in between. Bristles of segment II of antenna reaching about to middle of club, not beyond club as in T. tantillus. First and second row of occiput represented by one bristle each; subapical row with 7 bristles each side and one or two additional bristles at lower angle of occiput.

Anterior row of pronotum with 10 bristles on the two sides together, of mesonotum 7. Bristles on abdominal tergites: III 21, 20, IV 22, 18 ; and on sternite VII 9, 7, on sternite III about 31 , on the two sides together.

On outside of hindfemur 4 bristles in posterior half, on inside a row of 5 posteriorly and a single lateral bristle forward. On outside of hindtibia 6 or 7 dorsolateral and 4 or 5 ventrolateral bristles; six dorsal notches inclusive of apical one, in fourth notch 3 heavy bristles, in fifth 2 , stouter than in $T$. tantillus, 
longest dorsal apical bristle of hindtibia reaching to subapical notch of hindtarsal segment I, longest of this segment close to apex of II, and longest of II to near apex of $\mathrm{IV}$, these bristles shorter than in T. tantillus.

Modified Segments._- Sternite VI with a very small rounded lateral sinus (text-fig. 1); VII obliquely truncate, the margin slightly wavy. On each side

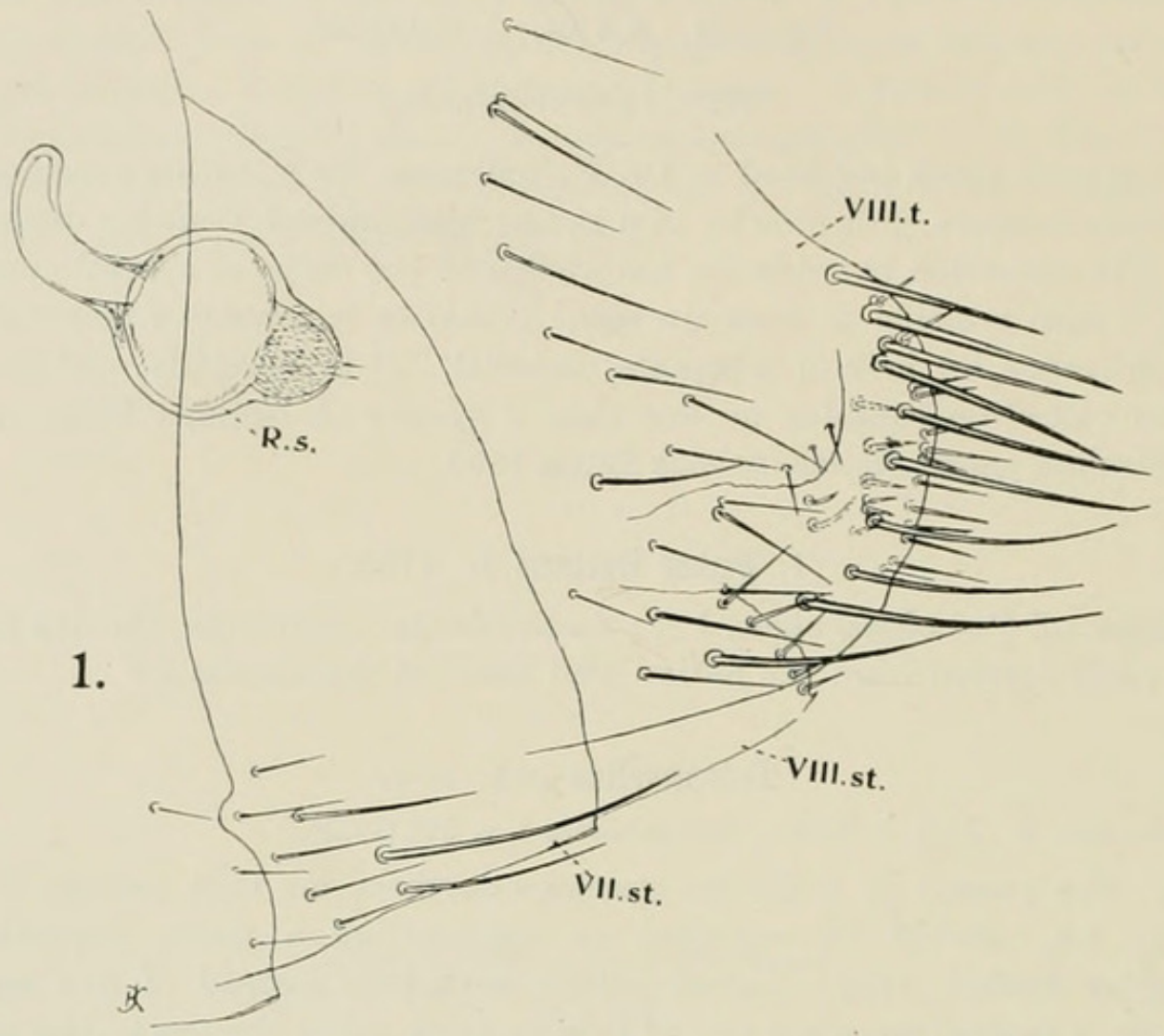

of tergite VIII 6 or 7 bristles above stigma, 15 or 16 from stigma downwards, and a row of 11 or 12 along ventral and apical margins, the upper marginal ones shorter and straighter than the lower ones and more numerous than in $T$. tantillus ;

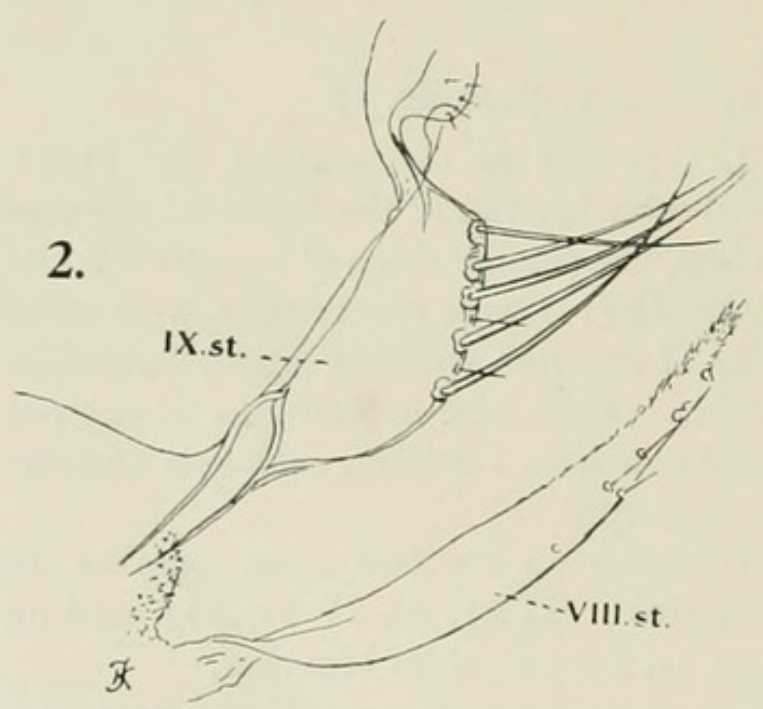
on inside at and near apical margin about 20 bristles, most of them short and spiniform. Some of the bristles of VIII. t., double in this specimen. Sternite VIII with 5 apical bristles, which are larger than in $T$. tantillus. Spermatheca much larger, especially its head, than in T. tantillus.

Length $2 \mathrm{~mm}$., hindfemur $0.4 \mathrm{~mm}$. Chimborazo, on Sigmodon spec., 1 ㅇ.

\section{Ceratophyllus dolens quitanus} subspec. nov. (text-figs. 2, 3, 4).

About two years ago Dr. Carroll Fox submitted to me a male of a species of Ceratophyllus from Ecuador, which I identified as belonging to $C$. dolens J. \& R. 1914, known only from Costa Rica. I pointed out (in litt.) a small difference between this unique Ecuadorian male and the likewise unique Costa 
Rican one, a difference which I considered at the time as being perhaps purely individual. Dr. F. Spillmann has sent a male and several females, and these specimens prove that there are geographical differences between the Ecuadorian and Costa Rican examples, especially in the female.

${ }^{7}+$. As a rule, the frons bears three rows of bristles, but in one $q$ the middle row is missing, the numbers being : $0,4,4,3$, or $6,3,3$; 94 to 6,0 to 3,3 . As

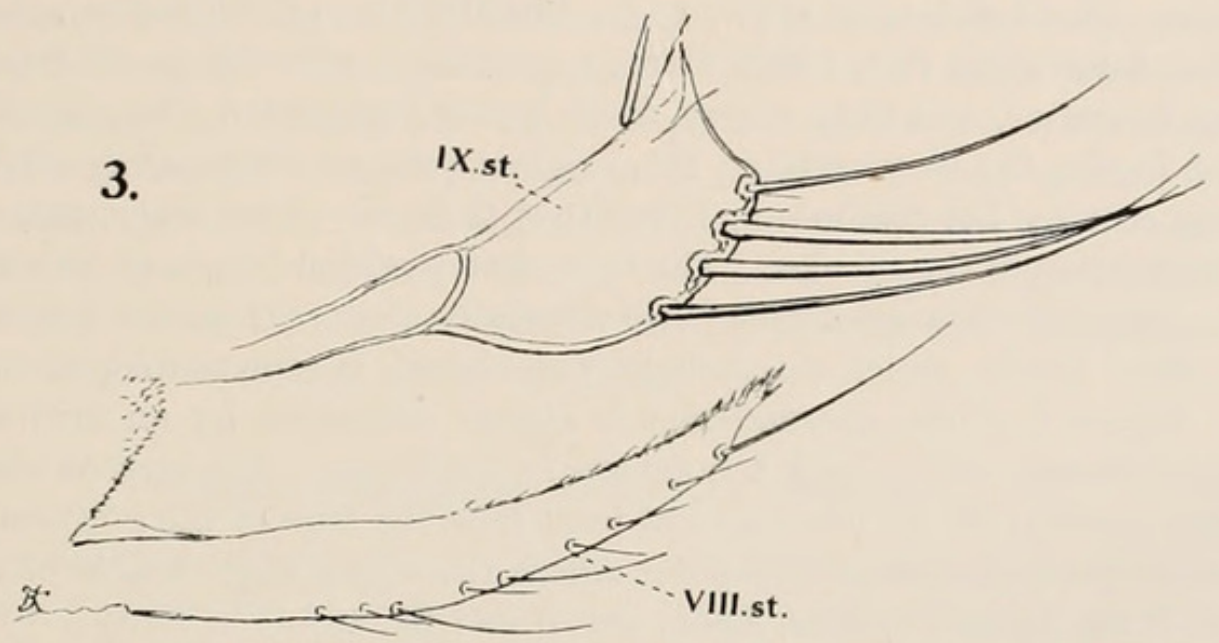

in $C$. dolens dolens and $C$. apollinaris J. \& R. 1921, the ridges on the lower twothirds of the basal abdominal sternite are very close together and, in the middle of the segment, are strongly curved backwards.

o. Median lobe of ventral arm of IX. st. with 4 or 5 long bristles instead of 3 (text-fig. 2), on right side the second distal bristle much thinner and shorter than the four others.

१. Upper and lower antepygidial bristles more than onethird the length of the middle one. Lateral lobe of st. VII more rounded than in $C . d$. dolens; on this sternite the posterior row contains on the two sides together 10 to 12 bristles, there being in front of the row 8 to 11 . The spermatheca of C.d. dolens was in a bad position for drawing; the outline of the organ is most probably the same as in the new subspecies, in which the head of the spermatheca is somewhat longer than broad and slightly widened towards the tail, which latter bears a small hooked appendage

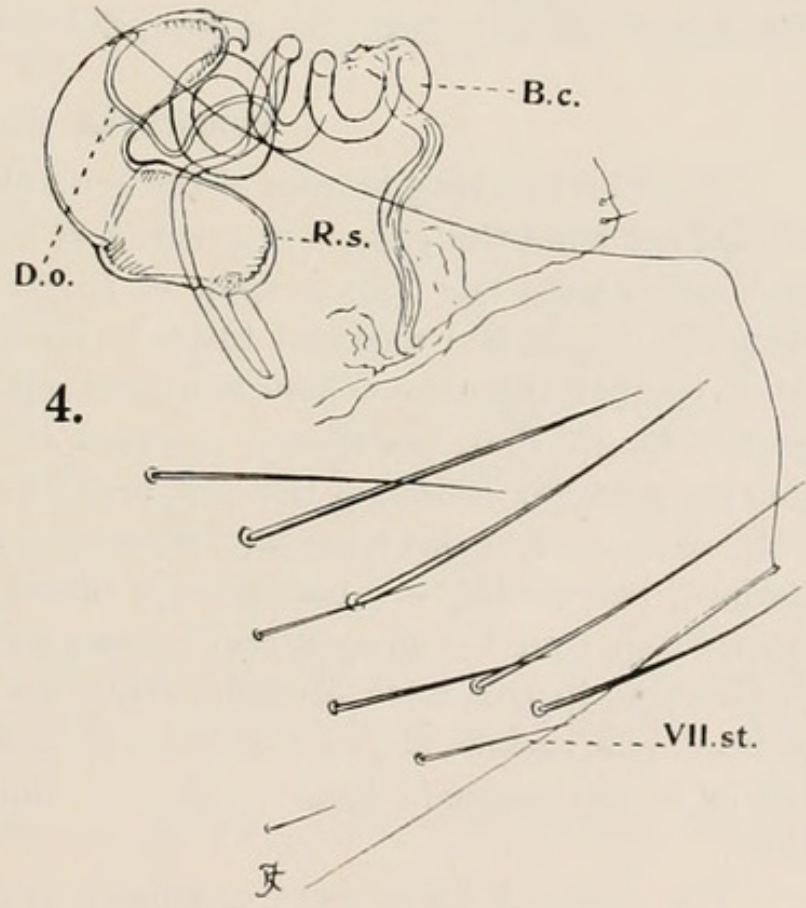
(text-fig. 4). The duct of the organ is rather wide, and the blind duct branches off from it at about one-fifth, not emanating directly from the bursa copulatrix.

Cerro de Puntas, off Oryzomys spec., $1 \hat{o}$ (type), 1 q, and off Thomasomys spec. 2 우; Chimborazo, off Thomasomys spec., 1 ㅇ. Also a $\hat{\sigma}$ in coll. Carroll Fox, with 4 bristles on st. IX, from near Quito (text-fig. 3, more enlarged than fig. 2). 
4. Neotyphloceras rosenbergi Roths. 1904.

Iliniza, off Thomasomys spec., 1 ô; Chimborazo, off the same host and Sigmodon spec., 2 우으. In a former consignment Professor Spillmann sent a $\hat{\sigma}$ and several 우 taken off Didelphys azarae at Quito and on Mt. Pichincha.

\section{Cleopsylla townsendi J. \& R. 1914.}

Iliniza, off Thomasomys spec., 1 ô; Chimborazo, off Sigmodon spec., $1 \hat{o}$, 1 ‥-This interesting flea, which forms a transition towards the Helmed Fleas following hereafter, was only known from a pair obtained by Townsend in the Andes of Peru. On re-examining this original pair and comparing with it the specimens sent by Dr. Spillmann, I find that there are a few slight inaccuracies in the description of the species. The lower antepygidial bristle is drawn a little too long, being in all 5 specimens more decidedly shorter than the bristle above it ; the third bristle, which we thought was absent, is represented by a minute bristle. The tail of the spermatheca is almost concealed by an air-bubble in the original female and is much too narrow in the figure. The present two males show that the sternite IX has a sort of joint near the base of the horizontal arm, this sclerite being flexible at the point where the upper large bristle of st. VIII is placed in our figure (cf. Nov. ZooL. xxi, p. 247 fig. 10).

On p. 314 of Nov. ZooL. xxxvi, I said under Craneopsylla tolmera that one might be in doubt as to whether the various forms of Craneopsylla represented three genera, each with several species, or three species, each with several subspecies. The present collection decidedly favours the first alternative, and I therefore propose two new genera for the species which come into Sections A and B.d. of our key on p. 250 of Nov. ZooL. xxi (1914).

Plocopsylla gen. nov.

§ิ․ The two long bristles of the gena placed near the suture which separates the helmet from the gena. Segment I of maxillary palpus about one-fourth (or less) longer than II. Sixth spine of frontal comb (counted from above) longer than the others and widened towards apex. Upper spine of genal comb very much smaller than the others and well separated from them, or absent; genal process longer than the spines, rounded at apex. Spines of pronotal comb not sharply pointed. Some of the long bristles of abdominal sternite VII and tergite VIII of $q$ arched downwards. Incrassation of basal abdominal sternite very distinct, resembling a squat $\mathrm{Y}$ with broad $\hat{o}$ foot. Clasper ending as a soleshaped flap, rounded at apex and bearing a close-set marginal row of long bristles. q, Head of spermatheca almost evenly convex dorsally and concave ventrally, or its dorsal surface slightly concave in middle, no such hump dorsally towards tail as in Craneopsylla Roths. 1911._-Genotype: Craneopsylla achilles Roths. 1911.

The Helmed Fleas were originally parasites of Marsupials and have gone over to Rodents. Their range in America embraces the Andesian countries from Southern Argentina to Ecuador (probably extending farther north) and includes Paraguay. They are evidently absent from Brazil. Their distribution agrees with that of Parapsyllus and Tetrapsyllus, and they have, like these genera, a close affinity with the Australian fauna. 
6. Plocopsylla achilles Roths. 1911.

Iliniza, Cerro de Puntas and Chimborazo, off Thomasomys spec., 3 $\widehat{o} \widehat{o}$, 4 우; Cerro de Puntas, off Oryzomys spec., 1 i ; Iliniza, off Coenolestes spec., 19. The species was described from a single male obtained at Chota, Ecuador, on Oryzomys albigularis, and no further specimens had come to hand until Professor Spillmann sent the series here recorded. The males agree very well with the type, which is in the British Museum and the female agrees in chaetotaxy closely with the male. The two antepygidial bristles are, in the female, twice the length of hindtarsal segment IV ; the helmet is as narrow as in the male. The first three notches of the hindtibia bear as in of a pair of stout bristles, the other four notches three bristles, the outer dorsal bristles not forming a comb. On the outer surface of hindtibia a dozen bristles or more. Spermatheca as in P. wolffsohni Roths. 1909, but its head widened towards tail. In one female the small genal spine is missing on the left side.

7. Plocopsylla phobos spec. nov. (text-figs. 5, 6).

วิ․ Similar to $P$. achilles, but the spines of the genal comb shorter and the short upper spine absent. The pronotal comb contains only 14 spines. The antepygidial bristles shorter than hindtarsal segment IV in ô, about one-third longer than that segment in 9 . Bristles on abdominal tergite VI in $\hat{o} 2,14$, in 8,12 , on $\mathrm{VII}$ in $\hat{\sigma} 2,13$, in ㅇ 8,9 .

o. The dorsal apical bristle of IX. t., thinner than in P. achilles; the second stout spiniform of IX. st. closer to the first (rod-like) one, the latter shorter than in $P$. achilles, and the sole-like end-portion of the clasper narrower. Apical margin of exopodite $\mathrm{F}$ excised, the angle below the sinus appearing double and the upper angle very sharp ; the large spiniform of $\mathrm{F}$ broader than in $P$. achilles and its wide apical portion longer.

ㅇ. Abdominal sternite with fewer bristles than in $P$. achilles: on the two

5.
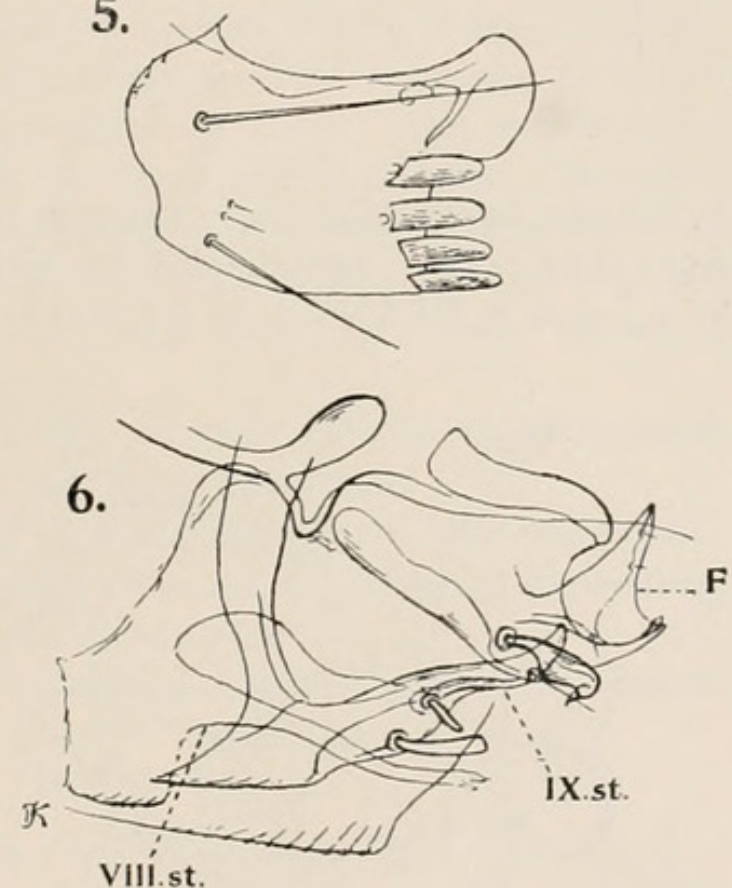
sides together of III 6 , IV 6 , V 4, VI 4, VII 13 ; on each side of IX. t. 19 . Stylet somewhat broader and head of spermatheca narrower than in $P$. achilles. The genal spines shorter than in $\hat{\jmath}$.

Chimborazo, off Thomasomys spec., 1 ô (type); Cerro de Puntas, off the same host, 1 우.

8. Plocopsylla hector spec. nov. (text-figs. 7, 8, 9).

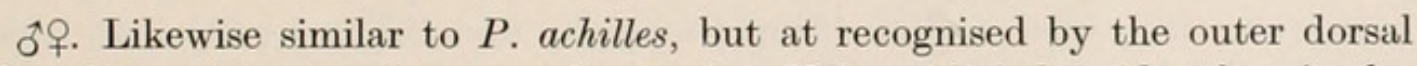
bristles of the tibiae forming a regular comb. Helmet slightly wider than in the previous two species. Upper spine of genal comb absent, the other four as in 
$P$. achilles, but the genal process broader than in that species. Apart from the legs, the chaetotaxy almost the same as in $P$. achilles: on mesonotum some additional bristles representing an anterior third row, in female such additional bristles also on pronotum; antepygidial bristles somewhat longer than in
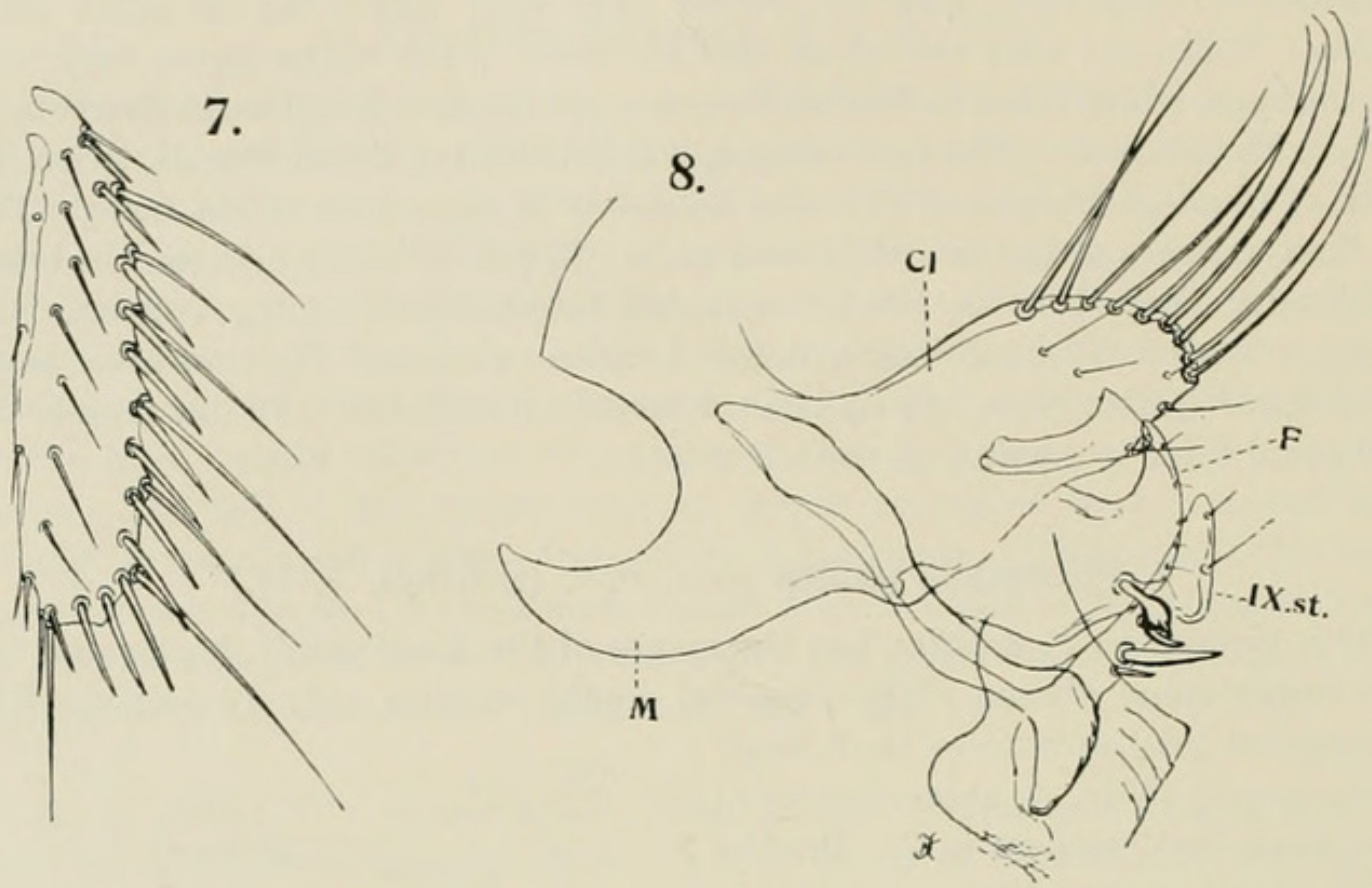

$P$. achilles, being in $\sigma^{-}$nearly twice as long as segment IV of hindtarsus and in $q$ more than twice. Apical spines on abdominal tergites (the two sides together), in $\hat{o}$ I 9, II 8, III 5, IV 1 , in 우 I 10-12, II 9-10, III 6, IV 0-4. The outer dorsal

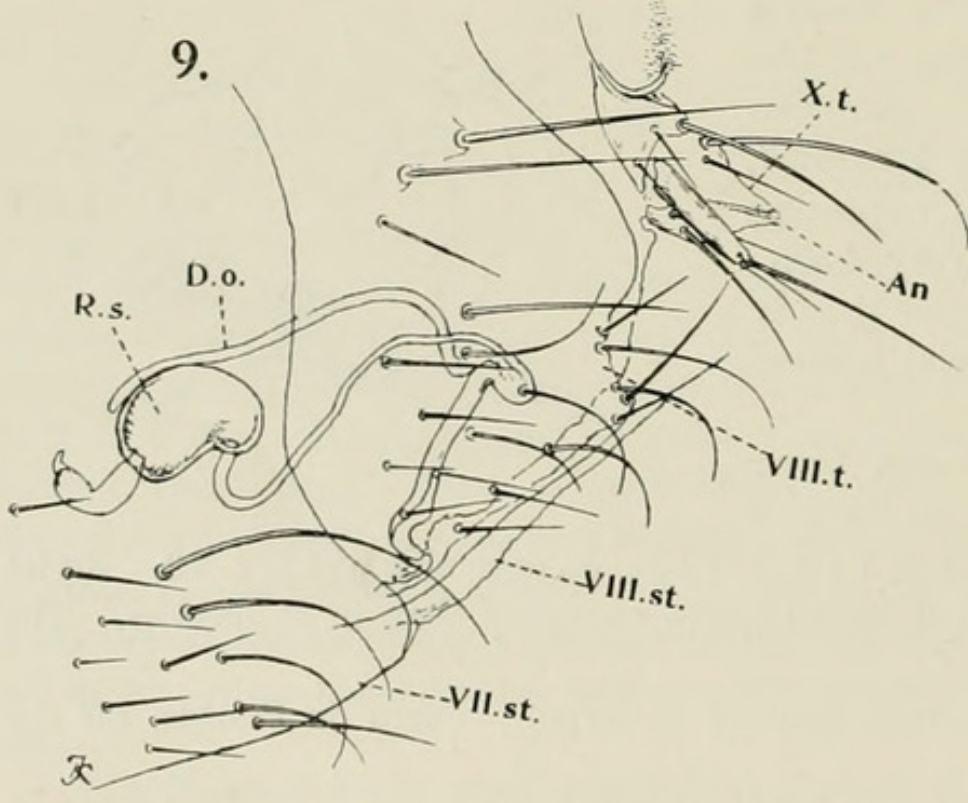
bristles of the tibiae form a comb; they are the same in length and thickness (practically) as the dorsal bristles adjoining the long inner ones and these dorsal marginal bristles are moved distad to a position in between the notches (text-fig. 7).

o. IX. st. with three spiniforms, which are close together, the first small, touching second, this the longest, pointed, the third about half the length of second, somewhat curved, obtusely pointed; beyond this group of spiniforms the sclerite moderately rounded-dilated ventrally, and then gradually narrowed, the apical section being triangular and bearing two short slender bristles at the posterior margin. Manubrium of clasper narrower than in $P$. achilles and strongly curved upwards. Sole-like apical portion of clasper 
somewhat broader and apically less evenly rounded than in the preceding two species, with only 9 long marginal bristles. Exopodite $\mathrm{F}$ claw-like, its apical half dorsally concave, curved upwards, pointed; the spiniform of $\mathrm{F}$ with asymmetrically globular apex, from which projects a small sharp curved claw (text-fig. 8).

․ The two straight apical bristles of VIII. t. (text-fig. 9) rather farther apart, and the lower one longer, than in P. achilles. Stylet slenderer, very little broader at base than near apex, four times as long as broad. Spermatheca not distinctly widened towards tail.

Iliniza, off Thomasomys spec., 1 oิ, 2 우우.

Sphinctopsylla gen. nov.

숭. The lower genal bristle much farther back than the upper one. Upper spine of genal comb nearly as long as the others and contiguous with its neighbour, but triangular; genal process short, obliquely truncate. Sixth spine of frontal comb (counted from above) in shape like those near it, not distinctly widened apicad, the spines of this comb shorter than in Plocopsylla. Segment I of maxillary palpus nearly twice the length of II. Pronotal comb with more than 20 spines, the dorsal ones drawn out into a long thin point. Thoracic tergites with three rows of bristles, meso- and metanotum often with additional bristles. Longest antepygidial bristle of male nearly twice as long as hindtarsal IV, in female thrice. Downward projection (median) of meso- and metasternum longer than in Plocopsylla. Hindcoxa nearly as broad as long. Incrassation of the basal abdominal sternite restricted to the area of the anterior ventral angle, longer than broad, convex above, semilunar. Outer apical bristles of tibiae nearly like the outer dorsal ones, close-set, forming a comb.

o. Clasper distally truncate, without the marginal row of long bristles of Plocopyslla, exopodite F and IX. st. without heavy spiniforms.

․ Head of spermatheca divided by a deep constriction into a posterior globular portion bearing the duct and a longer and narrower anterior one bearing the tail._-Genotype: Craneopsylla tolmera Jord. 1931.

Here also belong $C$. mars Roths. 1898, $C$. ares Roths. 1911, and $C$. inca J. \&. R. 1914.

9. Sphinctopsylla tolmera Jord. 1931 (text-fig. 10).

Cerro de Puntas, off Thomasomys and Oryzomys spec., 1 ô, 3 우.——I described this species in Nov. ZooL. xxxvi, p. 314 text-fig. 5 (1931), from a single male discovered by Dr. Spillmann on Mt. Pinchincha. The male now received agrees well with the type. The female, as was to be expected, is very close to $S$. inca, but is not difficult to recognise by the smaller number of bristles on the abdominal tergites and on the outer side of the hindfemur. Number of apical spines on abdominal tergites, on the two sides together: I 6 to 8 , II 7 to 9 , III 4 or 6 , IV 2 or $6, \mathrm{~V} 1$ or 2 ; number of bristles: I 12 or 14,10 or 11 , II 15 to 18,19 to 22 , III 13 or 16,21 to 25 , IV 8 to 12,21 or $25, \mathrm{~V} 4$ to 8,19 , to 21 VI 3 to 5,16 to 19 , VII 3 to 5 , 11 to 13 . On VII. t. 23 to 26 bristles, besides 5 or 6 short spiniform ones on inside at margin. On VI. st. 8 or 9 on the two 
sides together, on VII. st. 12 to 15 , with a small bristles in front of the row, at least on one side, the row not interrupted. Two antepygidial bristles of equal lengths. Posteriorly on outside of hindfemur a subventral row of 3 or 4 bristles,

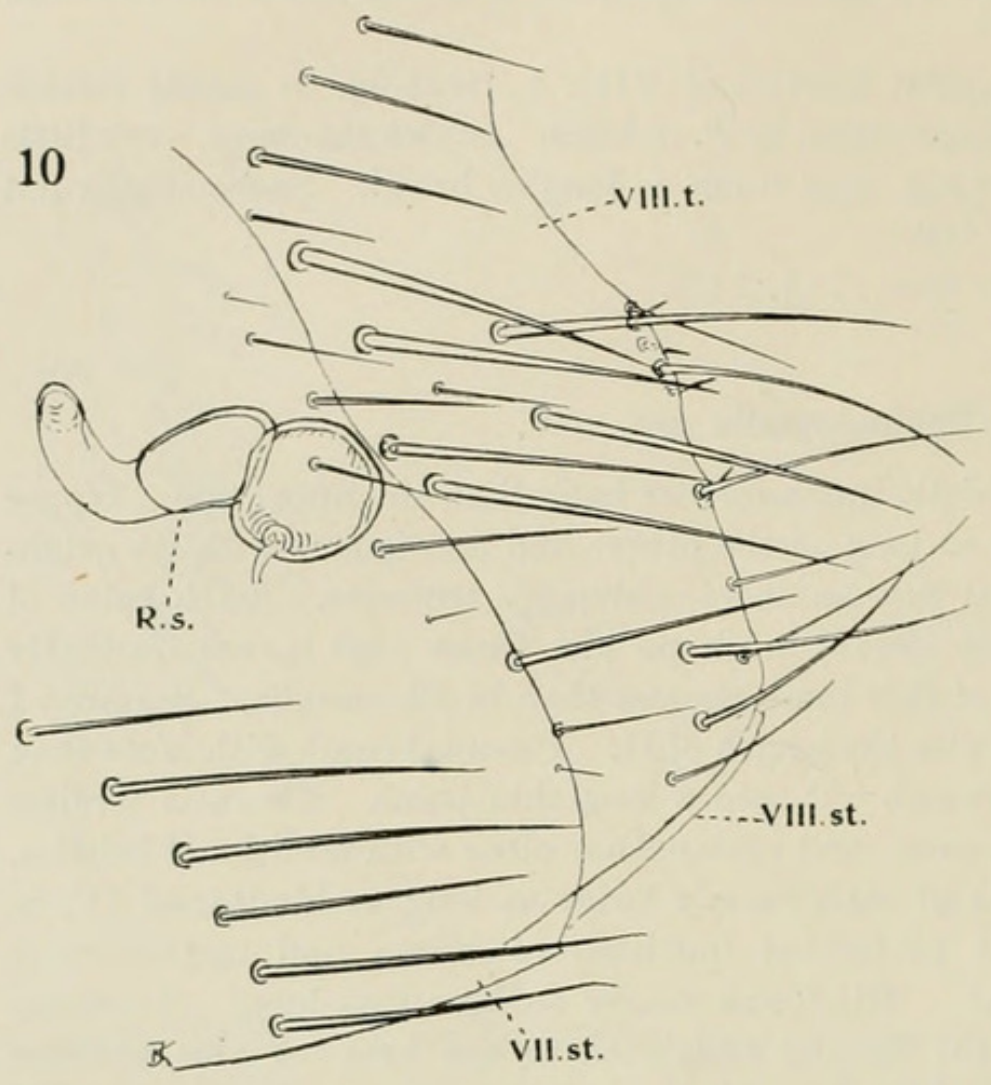
above which there are 2 or 3 lateral ones, farther forward no lateral bristles or only one far forward. Globular portion of spermatheca larger than in $S$. inca, the second partition a little longer than in that species and less elliptical, tail not much longer than this partition, conspicuously shorter than in S. inca.

\section{Sphinctopsylla inca}

J. \& R. 1914 (text-fig. 11).

Cerro de Puntas, off Oryzomys spec., 3 ठิ $\widehat{\jmath}, 3$ 우; Chimborazo, off Thomasomys spec., 1 ㅇ.— Only one female was known of this species, as is still the case with $S$. ares and $S$. mars. The male differs from that sex of $S$. tolmera conspicuously in the genital armature (text-fig. 11). Clasper (Cl) truncate, very broadly rounded ventrally, the upper angle somewhat projecting, but this lobe rounded, at upper angle a row of 4 bristles, of which the lowest is the longest ; between this row and the ventral end of the anterior margin of exopodite F 3 or 4 long marginal bristles, on the side 5 or 6 , which are shorter than the marginal ones, at and near dorsal margin proximally of the row 3 to 6 bristles. The tubercle on clasper proximally of apex of $\mathrm{F}$ conical, somewhat variable, like all detail. Exopodite $\mathrm{F}$ much narrower than in S. tolmera, sickle-shaped, its posterior margin more than eight times as long as $\mathbf{F}$ is broad in middle. IX. st. at apex with a long bristle and a very minute one.

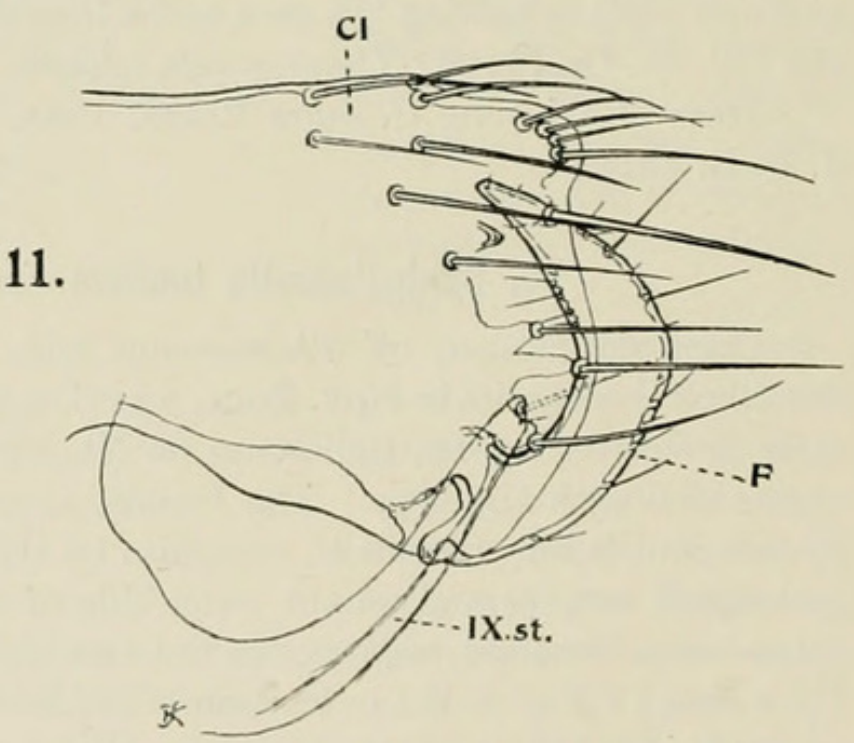

I append here the description of another flea from Ecuador, which has been in the collection for some time. 
11. Ceratophyllus campaniger spec. nov. (text-fig. 12).

+. Close to C. graphis Roths. 1909. As in that species the frons and occiput with three rows of bristles; the proboscis reaching to the end of the forecoxa; the bristles of antennal segment II short ; on mesonotum numerous small bristles from the posterior row to the base ; bristles above stigma of VIII. t. numerous ; those of anal sternite long and slender. Differs in the apical margin of VII. st.

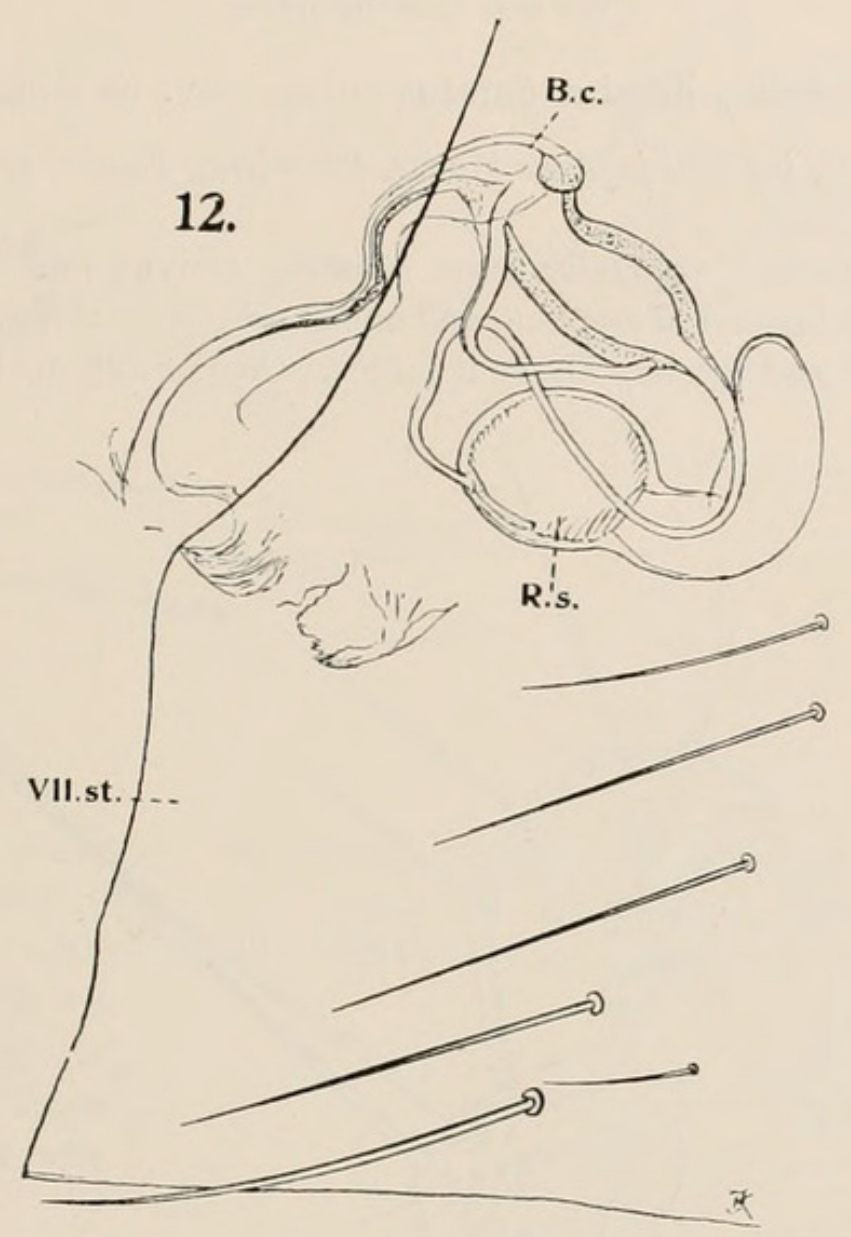

being much less slanting (text-fig. 12), in VIII. $t$. bearing 4 large bristles below the stigma and in the sexual organs: while the spermatheca is practically the same as in $C$. graphis, its duct begins with a large, bell-shaped, thick-walled swelling, which is longer than broad, being longer than the head of the spermatheca.

Ecuador (no more precise locality given), 1 found by the late Oldfield Thomas on a spirit specimen of Hesperomys (coll. Frazer) in the British Museum. 


\section{$2 \mathrm{BHL}$ Biodiversity Heritage Library}

Jordan, Karl. 1931. "Further records and descriptions of fleas from Ecuador." Novitates zoologicae : a journal of zoology in connection with the Tring Museum 37, 135-143. https://doi.org/10.5962/bhl.part.13257.

View This Item Online: https://www.biodiversitylibrary.org/item/22933

DOI: https://doi.org/10.5962/bhl.part.13257

Permalink: https://www.biodiversitylibrary.org/partpdf/13257

\section{Holding Institution}

Natural History Museum Library, London

\section{Sponsored by}

Natural History Museum Library, London

\section{Copyright \& Reuse}

Copyright Status: In copyright. Digitized with the permission of the rights holder.

Rights Holder: The Trustees of the Natural History Museum, London

License: http://creativecommons.org/licenses/by-nc-sa/4.0/

Rights: http://biodiversitylibrary.org/permissions

This document was created from content at the Biodiversity Heritage Library, the world's largest open access digital library for biodiversity literature and archives. Visit BHL at https://www.biodiversitylibrary.org. 